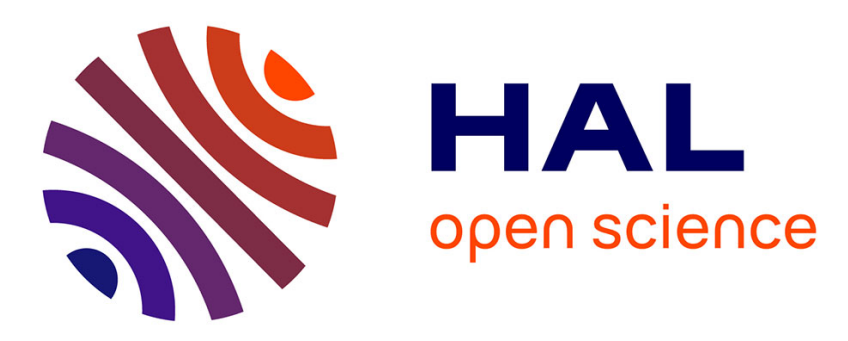

\title{
Heterogeneity of hydrogeological conceptual models in crystalline basement aquifers under equatorial climate: case study of French Guiana
}

Adrien Selles, Geoffrey Aertgeerts, Nicolas Brisset, Maxime Lhotelin

\section{- To cite this version:}

Adrien Selles, Geoffrey Aertgeerts, Nicolas Brisset, Maxime Lhotelin. Heterogeneity of hydrogeological conceptual models in crystalline basement aquifers under equatorial climate: case study of French Guiana. EGU General Assembly 2021 - Gather Online, Apr 2021, Online, France. hal-03130078

\section{HAL Id: hal-03130078 https: / hal-brgm.archives-ouvertes.fr/hal-03130078}

Submitted on 3 Feb 2021

HAL is a multi-disciplinary open access archive for the deposit and dissemination of scientific research documents, whether they are published or not. The documents may come from teaching and research institutions in France or abroad, or from public or private research centers.
L'archive ouverte pluridisciplinaire HAL, est destinée au dépôt et à la diffusion de documents scientifiques de niveau recherche, publiés ou non, émanant des établissements d'enseignement et de recherche français ou étrangers, des laboratoires publics ou privés. 


\section{Heterogeneity of hydrogeological conceptual models in crystalline basement aquifers under \\ equatorial climate: case study of French Guiana}

Selles. A. ${ }^{1}$, Aertgeerts, G. ${ }^{1}$, Brisset, N. ${ }^{1}$, Lhotelin, M. ${ }^{1}$

(1) BRGM, F-97333 Cayenne, France

Crystalline rocks aquifers are usually represented with a low porosity and hydraulic conductivity giving low well yields. Over the world, more than 880 millions people live on crystalline basement rocks. Thus, abilities to spot sufficient groundwater resource in these systems are crucial. Nevertheless, assessment of the sustainable reservoirs in crystalline basement aquifers is challenging. The well-admitted conceptual model presents a stratiform-weathered profile above a fractured zone showing a decreasing fracture density with depth. The interconnection between these two compartments defines the hydraulic parameters: the weathered profile is capacitive while the fractured zone is transmissive.

French Guiana is mostly composed of Paleoproterozoic rocks belonging to the Guiana Shield. It was formed during protracted periods of intense suprasubduction related magmatism, metamorphism and deformation, culminating with the Transamazonian orogeny, bracketed between 2.3 and $1.9 \mathrm{Ga}$. This peculiar geological history creates a large diversity of geological units from undeformed granitic units to ultramylonitized shearszone related meta-volcano-sedimentary units and through brittle to ductile deformed units. Furthermore, over almost $200 \mathrm{Ma}$, the French Guiana recorded a deep weathering phase leading to heterogeneous and complex profiles up to 80-100 $\mathrm{m}$ deep. In such a context, hydrogeological exploration is thus puzzling, especially as French Guiana is covered by the Amazonian Forest, reducing direct observations.

We use a multi-disciplinary method from remote sensing to field observations through geophysical tomography to propose conceptual models of groundwater circulation helping us to localise precisely (meter scale) exploration borewells. After 15 years of hydrogeological surveys, the BRGM has studied plural units: (i) classical isotropic unit (Mahury Massif (MM)) and Granitic unit (Mana), (ii) ductile to brittle deformed units separated by strike-slip fault (Rosebel-Bonidoro unit (RBU) and Armina Unit (AU)), (iii) ultramilonitized unit (Paramaca Unit $(\mathrm{PU}))$. A large heterogeneity of hydrogeological conceptual models for each context arise from our results. Notwithstanding this diversity and thanks to these conceptualizations, we were able to propose successfully useable sustainable resources, confirming the robustness of the method.

The MM and Mana are classical isotropic units displaying a deep weathered profile. The confined aquifer is located into the fractured layer with yield reaching $15 \mathrm{~m}^{3} \cdot \mathrm{h}^{-1}$. Crosscutting dolerite dyke is attested to be an interesting hydrogeological target with yield near $20 \mathrm{~m}^{3} \cdot \mathrm{h}^{-1}$. The highest yields in French Guiana for crystalline basement rocks $\left(30 \mathrm{~m}^{3} \cdot \mathrm{h}^{-1}\right)$ are found in confined aquifer in PU context. This record could be due to the ultramylonitic deformation giving a high permeable unit. Three different places were studied for the AU (Sparouine, Roura, Beauséjour). As for the PU, aquifers are all confined. Yields are systematically low (around 2$5 \mathrm{~m}^{3} \cdot \mathrm{h}^{-1}$ ). The RBU is an interesting and contrasting unit because it does not show developed weathered profile. It seems that an unconfined aquifer must probably recharge surroundings units (i.e. PU and $A U$ ).

This work highlights the high potential of ductile to ultramylonitic shear zones for groundwater resource. Taking together, these conceptual models highlight that, in French Guiana and probably in entire Guiana Shield, Transamazonian tectonometamorphic structures as well as early Jurassic extensive faults correspond to sustainable useable groundwater resources. 